\title{
Webs, diet, and fecundity of Theridion impressum (Araneae: Theridiidae)
}

\author{
STANISLAV PEKÁR
}

Research Institute of Plant Production, Drnovská 507, 16106 Praha 6 - Ruzyně, Czech Republic; e-mail: pekar@hb.vurv.cz

Key words. Spiders, Araneae, Theridion impressum, webs, diet, prey, fecundity, density, biological control

\begin{abstract}
Data on the webs, prey spectrum, density and fecundity of Theridion impressum from three different habitats [fields of sunflower, fiddleneck (Phacelia), and apple trees] are presented and discussed. The volume of webs were found to vary between 5 (the first free instar) to $117 \mathrm{~cm}^{3}$ (subadult and adult specimens). The mean density of adult spiders per plant was 0.7 (sunflower), 1.5 (fiddleneck) and 1.2 (per apple branch). Spiders preferred to build webs in the upper part of vegetation or at the extremities of tree branches. The prey spectrum was assessed by collecting webs and identifying their contents. Prey items were primarily aphids (73\%), Diptera (7.5\%), and Coleoptera and Hymenoptera (both 5.4\%). Pests comprised $90 \%$ of the prey; the remaining $10 \%$ was accounted for by natural enemies, pollinators and other insects. The number of insects captured in webs differed among study habitats (sunflower $>$ fiddleneck $>$ apple tree) though this difference was not statistically significant. Due to greater numbers of aphids in webs on sunflower, the mean prey length was significantly smaller on sunflowers than in other plots. An index of fecundity was obtained by counting the number of eggs in eggsacs. This varied from 48 to 156 per eggsac and was not significantly different between study plots. The number of eggs was strongly correlated with numbers of prey captured per spider.
\end{abstract}

\section{INTRODUCTION}

Serious study of the importance of spiders for the control of insect pests started fairly recently (e.g. Kiritani et al., 1972). This pioneering research focused on the whole community of spiders. Later investigations concentrated on a single or a few species of spiders considered to be important for biological control. Examples are Cheiracanthium mildei L. Koch in citrus apple trees in Israel (Mansour et al., 1980), Philodromus cespitum (Walckenaer) and Araniella opistographa (Kulczynski) in apple trees in Germany (Klein, 1988), Araniella cucurbitina (Clerck) in apple trees in Latvia (Anchipanova \& Shternbergs, 1987), and Lepthyphantes tenuis (Blackwall) in cereals in Great Britain (Samu et al., 1996). Autecological studies of biology, life-history, foraging, diet etc. yield important and valuable information. Such data are, however, still rather scarce (Sunderland, 1991).

During a five-year investigation of spiders in various agroecosystems (such as crop fields and commercial apple trees) in the Czech Republic (e.g. Pekár, 1999a), a few species of spiders were found to dominate these habitats. Among them Theridion impressum L. Koch was the most abundant canopy species. It is one of the most common spiders in Europe so there is quite a lot known about its biology (e.g. Nielsen, 1932; Kirchner \& Kullmann, 1975), although some aspects still remain to be unveiled. This species prefers to construct webs on low vegetation. The web is a dense, tangled, three-dimensional structure that incorporates a central retreat (Roberts, 1995). The most remarkable and well-known fact about this species is that the female feeds young spiderlings by regurgitation (Kullmann, 1969). In my research, I aimed to collect data necessary for parametrisation of variables (such as web density, mean abundance, and fecundity) that are going to be used in a mathematical model simulating the population dynamics of this species.

\section{MATERIAL AND METHODS}

The investigation was carried out in Prague-Ruzyně, the Czech Republic, in the area surrounding the Research Institute of Crop Production. Since this spider species occurs in a wide variety of habitats, three different plots were used in the study. A plot of sunflower $\left(230 \mathrm{~m}^{2}\right)$, a plot of fiddleneck (Phacelia tanacetifolia) $\left(960 \mathrm{~m}^{2}\right)$, and an apple tree plot of 20-year old "Spartan" trees $\left(1,430 \mathrm{~m}^{2}\right)$. None of the study plots were treated with agrochemicals during the study.

The investigation included estimation of web volume, spider density, web site quantity, prey spectrum, and fecundity. Web volume was estimated by measuring the three dimensions. Since the web volume was less than obtained rectangular volume, the figure was multiplied by $2 / 3$ to acquire a better estimate. Thirty webs were measured for each of three developmental stages; juvenile webs on 24 April, subadult + adult webs on 22 June, and webs of the first free-living instar on 26 August 1998.

On each plot, the number of sub-adult or adult spiders was counted on 25 randomly chosen plants or branches on 1 July 1998. At the same time the number of possible web sites was estimated as the number of leaves/twigs per plant (sunflower and fiddleneck) and per $50 \mathrm{~cm}$ of branch (apple tree) in 15 replications.

The prey spectrum was assessed by collecting entire webs on three dates; 1, 15, and 29 July 1998. A two-week sampling interval appeared to be sufficient for the study of web contents. Six webs were collected from each study plot on each date. Captured insects were then picked out and identified in the laboratory. Identification was the most difficult task since more than $90 \%$ of the insects readily disintegrated as they had been sucked out by the spider. Sucked aphids were recognised from exuviae by pigmentation. Therefore, many insects were identified only to order or family.

An index of fecundity was obtained by collecting 20 eggsacs on each study plot on 15 July 1998. Eggsacs were opened in the laboratory and the number of eggs counted. In addition, the diameter of 25 eggs was measured.

Because some of the data obtained did not meet assumptions (homogeneity of variance and normal distribution) required for 
parametric statistics, 3-sample randomization tests (Manly, 1997) were used to test for differences between plots.

\section{RESULTS AND DISCUSSION}

Webs

The web volume increased as the individuals became adult. Spiders in the first free-living instar often made webs below the lower surface of leaves. Mean web volume ( $\pm \mathrm{SE}$ ) was $5.0 \pm 1.13 \mathrm{~cm}^{3}$. Later instars occurring in spring constructed larger webs $\left(64.3 \pm 13.9 \mathrm{~cm}^{3}\right)$ which were spun between two stems of plants or twigs of tree branches. Subadult and adult spiders made webs (mean volume $117.6 \pm 12.2 \mathrm{~cm}^{3}$ ) in the same way as immatures.

Since a three-dimensional web requires many supports, $T$. impressum made its web among twigs. There were on average $7.2 \pm 0.41$ leaves per $70 \mathrm{~cm}$ tall sunflower plant, $5.1 \pm 0.33$ twigs per $50 \mathrm{~cm}$ tall fiddleneck plant, and 6.85 \pm 0.59 twigs per $50 \mathrm{~cm}$ long branch of an apple tree. So if all web sites were occupied there could be up to 7 subadult or adult spiders per plant or branch. However, this investigation revealed that there were only $0.73 \pm$ 0.02 spiders per sunflower, $1.5 \pm 0.61$ per fiddleneck, and $1.2 \pm 0.14$ per apple branch. Such a low number could re- sult from preference for a specific site position as $72 \%$ $(n=90)$ specimens were observed to build webs in the upper part ( $>2 / 3$ of height) of vegetation or at the extremities of tree branches. Other factors such as interspecific competition may have contributed to the low density to a certain extent. Which factors (and to what extent) are responsible for this effect remains to be investigated.

\section{Prey spectrum}

The prey spectrum is displayed in Table 1. In total 963 individual insects and one spider were collected from webs. Nine percent of captured insects had not been sucked out by the spiders and so there were probably cases of superfluous killing or prey avoidance. Aphids were the most frequent prey on all plots $(73 \%$ on average), followed by Diptera (7.5\%), Coleoptera and Hymenoptera (both $5.4 \%$ ). Likewise, aphids were the dominant prey of $T$. impressum in a study conducted in cereal fields of eastern Switzerland (Nyffeler \& Benz, 1979; Nyffeler, 1982) and in an investigation carried out in an apple tree in Kazakhstan (Sheikin \& Tarabaev, 1990). Although most of the captured insects were pests, other insects such as predators (adults of Chrysopa car-

TABLE 1. Prey spectrum of Theridion impressum. The numbers represent total prey items from 18 webs collected in three habitats (sunflower, fiddleneck, apple tree).

\begin{tabular}{|c|c|c|c|c|}
\hline & Sunflower & Fiddleneck & Apple tree & $\%$ \\
\hline Araneae & & & & 0.1 \\
\hline Theridion impressum & 1 & & & 0.1 \\
\hline Dermaptera & & & & 0.1 \\
\hline Forficula auricularia $\mathrm{L}$. & & & 1 & 0.1 \\
\hline Heteroptera & & & & 1.9 \\
\hline Lygus sp. & 2 & 7 & 2 & 1.1 \\
\hline Orius sp. & 2 & 3 & 3 & 0.8 \\
\hline Homoptera & & & & 78.0 \\
\hline Psylla sp. & & & 22 & 2.3 \\
\hline Typhlocyba sp. & 10 & 5 & & 1.6 \\
\hline other Cicadidae & 3 & 8 & 3 & 1.5 \\
\hline $\begin{array}{l}\text { Aphididae [Aphis fabae Scopoli, Brachycaudus helichrysi } \\
\text { (Kaltenbach), Metopolophium dirhodum (Walker)] }\end{array}$ & 372 & 176 & 151 & 72.6 \\
\hline Neuroptera & & & & 1.1 \\
\hline Chrysopa carnea Stephens & 3 & 5 & 3 & 1.1 \\
\hline Coleoptera & & & & 5.4 \\
\hline Carabidae & 1 & 1 & 1 & 0.3 \\
\hline Staphylinidae & 7 & 7 & 1 & 1.6 \\
\hline Agriotes sp. & 1 & 3 & 3 & 0.7 \\
\hline Coccinella septempunctata $\mathrm{L}$. & 2 & 1 & & 0.3 \\
\hline Phyllotreta sp. & 2 & 9 & 2 & 1.3 \\
\hline Chaetocnemasp. & & 7 & 5 & 1.2 \\
\hline Lepidoptera & 3 & 2 & & 0.5 \\
\hline Diptera & & & & 7.5 \\
\hline Syrphidae & & 2 & & 0.2 \\
\hline other Diptera & 23 & 21 & 26 & 7.3 \\
\hline Hymenoptera & & & & 5.4 \\
\hline Chalcidoidea & 6 & 7 & 2 & 1.6 \\
\hline Apis mellifera $\mathrm{L}$. & & 9 & & 0.9 \\
\hline Bombus sp. & & 1 & & 0.1 \\
\hline other Apidae & & 2 & & 0.2 \\
\hline Formica sp. & & & 4 & 0.4 \\
\hline Lasius sp. & 1 & & 16 & 1.8 \\
\hline Myrmica sp. & & & 4 & 0.4 \\
\hline Mean prey items / web $( \pm \mathrm{SE})$ & $24.4(3.73)$ & $15.3(2.27)$ & $13.8(2.69)$ & \\
\hline Total & 439 & 276 & 249 & \\
\hline
\end{tabular}




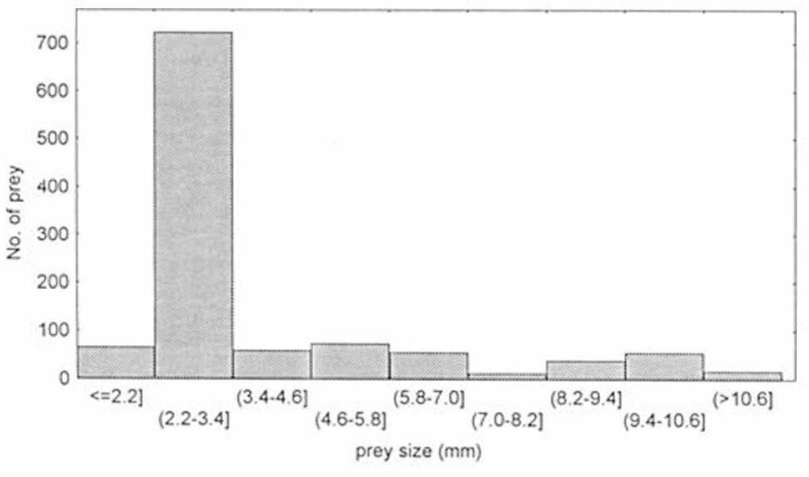

Fig. 1. Distribution of prey size of Theridion impressum from all webs collected in three habitats.

nea, Carabidae, Staphylinidae, ants, and both larvae and adults of Coccinella septempunctata), parasitoids (Chalcidoidea), and pollinating insects (Apidae) were also preyed upon by $T$. impressum. This kind of prey comprised $10.2 \%$ of the total. Similarly, Paulian (1991) observed $T$. impressum feeding on natural enemies (Chrysopidae, Carabidae, Coccinellidae and Syrphidae) in corn fields.

The number of prey captured in webs differed between study plots (Table 1). The greatest number of insects was caught in webs on the sunflower plot (24.4), followed by fiddleneck (15.3) and the least in the apple tree (13.8), however, the difference was not significant $(P=0.22,3-$ sample randomization test, 4,999 simulations). This distinction is primarily due to greater aphid numbers on sunflower.

The mean length of captured insects was significantly smaller in webs from the sunflower plot $(3.8 \pm 0.10 \mathrm{~mm})$, than in webs collected on fiddleneck $(4.74 \pm 0.36 \mathrm{~mm})$ or in the apple tree $(4.52 \pm 0.15 \mathrm{~mm})(\mathrm{P}<0.01,3$-sample randomization test, 4,999 simulations). This difference results from dissimilar aphid numbers in webs on the three study plots. The size of aphids (approx. $3 \mathrm{~mm}$ ) may be the preferred prey length for this species (Fig. 1).

\section{Index of fecundity}

The eggs were of cream colour, did not stick to each other and rolled freely. They had a mean diameter $( \pm \mathrm{SE})$ of $0.62 \pm 0.01 \mathrm{~mm}$ and were enclosed in a greenish eggsac. The number of eggs per eggsac varied between

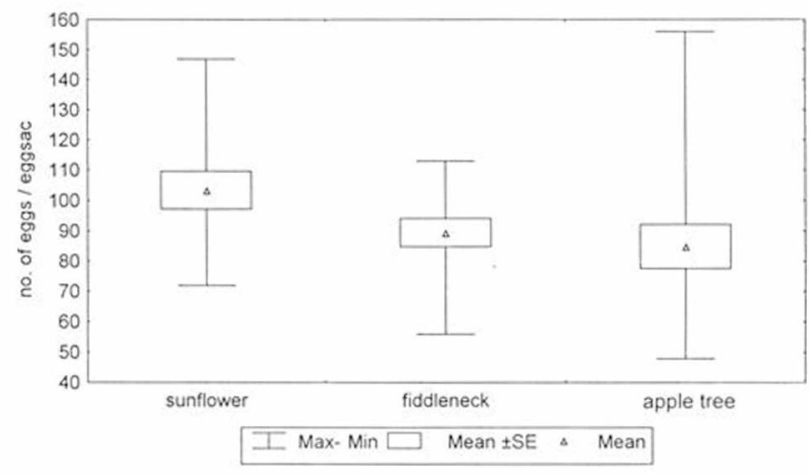

Fig. 2. Comparison of the number of eggs in 20 eggsacs of Theridion impressum between the study habiats.

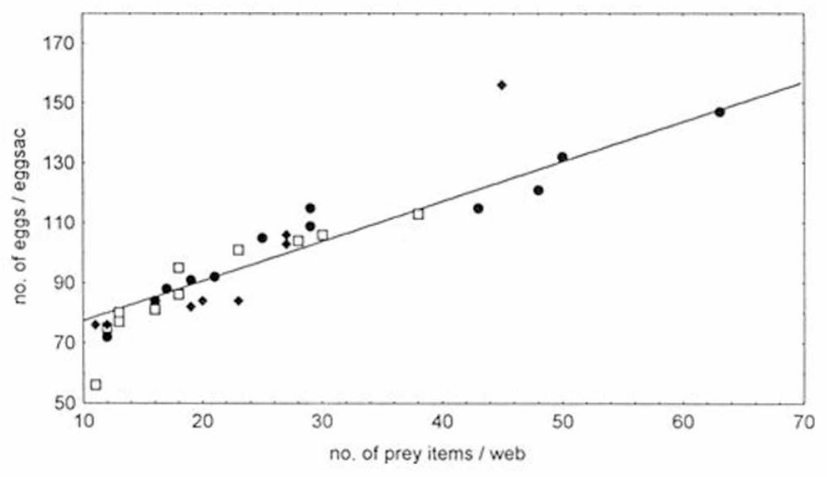

Fig. 3. Relationship between mean number of eggs per T. impressum eggsac and the number of prey items caught per web on study plots ( sunflower, $\square$ fiddleneck, $\bullet$ apple tree).

48 and 156. Fecundity (i.e. the total number of eggs laid by a female during her life) varies considerably among spider species, from 3 in Synageles venator (Lucas) up to 2,500 in Cupiennius salei (Keyserling) (Foelix, 1996). Egg number is a function of food quality and quantity, the size of the spider (Kessler, 1971; Toft, 1976) and the level of brood care (Foelix, 1996). In other theridiid spiders of similar size as $T$. impressum, the mean number of eggs was 109 (in the first eggsac) in Achaearanea lunata (Clerck), 26 (in the second eggsac) in Theridion varians Hahn, and 83 (in the first eggsac) in Enoplognatha ovata (Clerck) (Toft, 1976; 1978). These figures are very close to the number of eggs in an eggsac of $T$. impressum. I have not determined how many eggsacs are produced by T. impressum, but taking into an account brood-care of this species (Hirschberg, 1969), phenology (Pekár, 1999b), and observations during this study it appears that females of $T$. impressum produce a maximum of one or two eggsacs.

The mean number of eggs per eggsac varied between study plots (Fig. 2), but the difference was not significant $(\mathrm{P}=0.10$, 3-sample randomization test, 4,999 simulations). Most eggs were found in eggsacs from sunflower (103.4), followed by fiddleneck (89.5) and apple tree (84.8). The number of eggs produced was strongly correlated with the number of prey items captured $(r=0.92, P$ $<0.01$, Pearson correlation) with a model: $y=58.1+$ $1.56 * x$ (Fig. 3). This supports the hypothesis that, beside other factors [such as temperature and latitude (Lang, 1996; Toft, 1976)], food consumption markedly affects fecundity (e.g. Wise, 1975; Downes, 1988).

\section{CONCLUSIONS}

Data on the biology of Theridion impressum, a webbuilding spider commonly found in apple trees and crop fields, were collected. This polyphagous spider was observed capturing primarily insect pests, in particular aphids. Based on its abundance and feeding habits one can assume that $T$. impressum is a potentially important control agent. In the near future, the data obtained during this investigation will be used for a mathematical model simulating the population dynamics of this species. 
ACKNOWLEDGEMENTS. I wish to thank K.D. Sunderland, M. Nyffeler, and an anonymous referee for comments and some alterations to the English. The research was supported by grant no. 522/97/0271 of the Grant Agency of the Czech Republic and grant no. EP0960006431 of the Czech Ministry of Agriculture.

\section{REFERENCES}

Anchipanova Y.Y. \& Suternibrgs M.T. 1987: The diet of the dominant species of spiders (Aranei) of the apple-tree agrobiocoenosis. Trudy Latv. Sel'skokhoz. Akad. 237: 10-14 (in Russian).

Downes M.F. 1988: The production and use of inviable eggs by Theridion rufipes Lucas (Araneae: Theridiidae). In: Proceedings of a Symposium on Australian Arachnology, Adelaide, Australia, May 1986. Austr. Entomol. Soc. Misc. Publ. No. 5. Australian Entomological Society, Adelaide, pp. 127-135.

Foelix R.F. 1996: Biology of Spiders. 2nd ed. Oxford University Press, New York, $330 \mathrm{pp}$.

Hirscirberg D. 1969: Beiträge zur Biologie, insbesondere zur Brutpflege einiger Theridiiden. Z. Wiss. Zool. 179: 189-252.

KESSLER A. 1971: Relation between egg production and food consumption in species of the genus Pardosa (Lycosidae, Araneae) under experimental conditions of food-abundance and food-shortage. Oecologia 8: 93-109.

Kircinner W. \& Kullmann E. 1975: Überwinterung und Kälteresistenz der Haubennetzspinnenarten Theridion impressum (L. Koch) und Theridion sisyphium (Clerck) (Araneae, Theridiidae). Decheniana 127: 241-250.

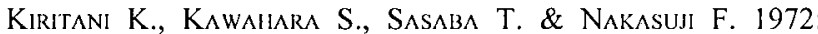
Quantitative evaluation of predation by spiders on the green rice leafhopper, Nephotettix cineticeps Uhler, by a sightcount method. Res. Popul. Ecol. 13: 187-200.

KLEIN W. 1988: Erfassung und Bedeutung der in den Apfelanlangen aufgetretenen Spinnen (Araneae) als Nützlinge im Grossraum Bonn. Ph.D. Dissertation, Rheinische FriedrichWilhelms-Universität Bonn, $134 \mathrm{pp}$.

Kullmann E. 1969: Unterschiedliche Brutfürsorge bei den Haubennetzspinnen Theridion impressum (L. Koch) und Theridion notatum (Clerck) (Araneae, Theridiidae). Zool. Anz. Suppl. 33: 326-333.

LANG G.P. 1996: Variation in egg production of Pityohyphantes phrygianus (C.L. Koch) (Linyphiidae, Araneae), influenced by temperature and latitude. In Mahnert V. (ed.): Proceedings of the XIIIth International Congress of Arachnology, Geneva, 3-8 September 1995. Rev. Suisse Zool. (Hors série): 377-381.

ManLy B.J. 1997: Randomization, Bootstrap and Monte Carlo Methods in Biology. Chapman and Hall, London, 99 pp.

Mansour F., Rosen D. \& Silulov A. 1980: Biology of the spider Chiracanthium mildei (Arachnida: Clubionidae). Entomophaga 25: 237-248.
Nielsen E. 1932: The Biology of Spiders, With Special Reference to the Danish Fauna. Levin \& Munskgaard, Copenhagen, $248 \mathrm{pp}$.

NYFFELER M. 1982: Field Studies on the Ecological Role of the Spiders as Predators of Insects in Agroecosystems. Ph.D. Dissertation, Swiss Federal Institute of Technology, Zurich, 174 $\mathrm{pp}$.

Nyffeler M. \& Benz G. 1979: Studies on the ecological importance of spider populations for the vegetation of cereal and rape fields. Z. Angew. Entomol. 87: 348-376.

PAULIAN M. 1991: Prezența şi rolul speciei Theridium impressum (Koch) (Aranea Theridiidae) in limitarea populațiilor unor entomofagi gi din culturile de porumb şi sfeclă de Zahăr [The presence and the role of the species Theridium impressum (Koch) (Aranea Theridiidae) in limiting some population of entomophages in maize and sugarbeet crops]. Anal. Inst. Cerc. Pent. Prot. Plant. 24: 153-160 (in Romanian).

PeKÁr S. 1999a: Effect of IPM practices and conventional spraying on spider population dynamics in an apple orchard. Agric. Ecosyst. Envir. 73: 155-166.

PeKÁR S. 1999b: Life-histories and the description of developmental stages of Theridion bimaculatum (L.), Theridion impressum L. Koch and Theridion varians Hahn (Araneae: Theridiidae). Acta Soc. Zool. Bohem. 63: 301-309.

RoBERTs M.J. 1995: Spiders of Britain and North Europe. Harper Collins, London, $383 \mathrm{pp}$.

Samu F., Sunderland K.D., Topping C.J. \& Fenlon J.S. 1996: A spider population in flux: selection and abandonment of artificial web-sites and the importance of intraspecific interactions in Lepthyphantes tenuis (Araneae: Linyphiidae) in wheat. Oecologia 106: 228-239.

SIIEIKIN A.O. \& TARABALv C.K. 1990: [Study of the prey biomass amount of Theridium impressum in the apple tree biocenoses of Zailiisky Alatau.] Proc. Zool. Inst. U.S.S.R. Acad. Sci. 226: 38-44 (in Russian).

SunDERLAND K.D. 1991: The ecology of spiders in cereals. In: Proceedings of the 6th International Symposim on Pests and Diseases of Small Grain Cereals and Maize, Halle/Saale, pp. 269-280.

Tогт S. 1976: Life-histories of spiders in a Danish beech wood. Natura Jutl. 19: 5-40.

TOFT S. 1978: The life-history of Achaearanea lunata $(\mathrm{Cl}$.$) in$ Denmark, with a note on Theridion varians Hahn (Araneae: Theridiidae). Bull. Br. Arachnol. Soc. 4: 197-203.

WISE D.H. 1975: Food limitation of the spider Linyphia marginata: experimental food studies. Ecology 56: 637-646.

Received January 19, 1999; accepted May 6, 1999 